\title{
As feiras da agricultura familiar como território de práticas alimentares e sociabilidades ${ }^{1}$
}

\author{
Romilda De Souza Lima \\ Universidade Estadual do Oeste do Paraná - Francisco Beltrão- Paraná - Brasil \\ Ana Paula Cavali Fontana \\ Universidade Estadual do Oeste do Paraná - Marechal Cândido Rondon- Paraná \\ - Brasil
}

\section{Resumo}

Este trabalho apresenta alguns resultados e discussões sobre pesquisa concluída que se desenvolve em torno das relações entre agricultores-feirantes e consumidores, referente ao processo de comercialização e às demais interações possíveis, em dois municípios do Oeste do Paraná: Marechal Cândido Rondon e Medianeira. Os objetivos: analisar o significado e a importância das feiras para os atores envolvidos; analisar as representações das feiras nas práticas alimentares envolvendo hábitos, cultura, identidades alimentares e identidades produtivas. A abordagem teórica norteadora do trabalho é da sociologia e antropologia rural e socioantropologia da alimentação. A metodologia foi essencialmente qualitativa, com aplicação de entrevista semiestruturada a 12 agricultores-feirantes; 10 consumidores em Marechal Cândido Rondon e 10 agricultores-feirantes; 10 consumidores em Medianeira. Dentre alguns resultados, é possível inferir que os frequentadores das feiras são atraídos não apenas pela opção de alimentos de origem que consideram como sendo mais confiável, mas também porque o espaço da feira lhes proporciona importantes interações com os agricultores e com outros frequentadores. Para os agricultores, a feira é uma importante fonte de renda, mas também é uma manifestação enquanto representação social, de suas peculiaridades como atores fundamentais no processo da cultura e da segurança alimentar. Neste sentido, é muito importante manter os espaços das feiras, compreendendo-as como lugares de resistência no processo socioalimentar contemporâneo e de articulação nas relações de sociabilidade local.

Palavras-chave: Cultura alimentar. Sociabilidades. Cadeias curtas. Agricultura Familiar.

\section{The familiar farming market-fairs as field of food practice and sociability}

\section{Abstract}

This paper presents some results and discussions about the research that is developed around the relationship between farmers-marketers and consumers, regarding the commercialization process and its possible interactions, in two towns in the West of Paraná:

\footnotetext{
${ }^{1}$ Um resumo sobre este trabalho foi publicado no Conference Proceedings do evento: III AgUrb, 2018 em Porto Alegre, RS.
} 
Marechal Cândido Rondon and Medianeira. The goals: to analyze the meaning and the importance of the market-fairs for the actors involved with it; to analyze the representations of the market-fairs on food practice involving habits, culture, food identities and productive identities. The theoretical approach guiding the work is from sociology and rural anthropology and socioanthropology of food. The methodology was essentially qualitative, with semi-structured interviews with 12 farmers-marketers; 10 consumers in Marechal Cândido Rondon and 10 farmers-marketers and 10 consumers in Medianeira. Among some results, it is possible to infer that the fair's frequent costumers are attracted by the option of buying food which origin they consider more trustworthy, but also because the market-fair's space offer them important interaction with the farmers and other costumers. To the farmers, the market-fair is an important source of income, but it also a manifestation of social representation, of their peculiarities as fundamental actors for the cultural process and for food security. In this sense, It is very important to keep the market-fair's space, understanding them as places of resistance in the contemporary socio-alimentary process and for the articulation of sociability relations.

Keywords: Food culture. Sociability. Short chains. Familiar farming.

\section{Las ferias de la agricultura familiar como un territorio de prácticas alimentarias y sociabilidad}

\section{Resumen}

Este trabajo presenta algunos resultados y discusiones sobre investigación que se desarrolla en torno a la relación entre agricultores que comercializan en ferias libres y consumidores, referente al proceso de comercialización ya las demás interacciones posibles, en dos municipios del Oeste de Paraná: Marechal Cândido Rondon y Medianeira. Los objetivos: analizar el significado y la importancia de las ferias de mercado para los actores involucrados; Analizar las representaciones de las ferias de mercado sobre prácticas alimentarias que involucran hábitos, cultura, identidades alimentarias e identidades productivas. El abordaje teórico orientador del trabajo es de la sociología y antropología rural y socioantropología de la alimentación. La metodología fue esencialmente cualitativa, con aplicación de entrevista semiestructurada en12 agricultores que comercializan en ferias libres; 10 consumidores en Marechal Cándido Rondon y 10 agricultores que comercializan en ferias libres; 10 consumidores en Medianeira. Entre algunos resultados, es posible inferir que los frecuentadores de las férias se sienten atraídos por la opción de comprar alimentos cuyo origen consideran más confiable, pero también porque el espacio de la feria les ofrece una interacción importante con los agricultores y otros clientes. Para los agricultores, la feria es una importante fuente de ingresos, pero también es una manifestación como representación social, de sus peculiaridades como actores fundamentales en el proceso de la cultura y la seguridad alimentaria. En este sentido, es muy importante mantener los espacios de las ferias, comprendiéndolas como lugares de resistencia en el proceso socioalimentario contemporáneo y de articulación en las relaciones de sociabilidad local.

Palabras clave: Cultura alimentaria. Sociabilidad. Cadenas cortas. Agricultura familiar.

\section{Introdução}

Na contemporaneidade, em função do estilo de vida acelerado, estilo este, que já atinge também os municípios de médio porte, as práticas alimentares passam por alterações e adaptações. Dentre elas, inserem-se as formas adotadas de consumo e de aquisição de alimentos. Se em tempos passados o ato de alimentar, para a maioria das pessoas, envolvia maior dedicação - sobretudo, nas áreas rurais e cidades 
médias e pequenas - nos tempos atuais da vida rápida e do não perder tempo, a praticidade tem se tornado quase que primordial para suprir as necessidades fisiológicas do organismo. Isso reflete nas relações de comensalidade e em vários aspectos relativos ao alimentar-se, incluindo os sociais, culturais e econômicos.

Nesse sentido, o processo de escolha alimentar interfere diretamente nos hábitos alimentares. Uma dessas interferências inclui a substituição, ou a redução, de produtos in natura por aqueles processados e ultraprocessados. Por outro lado, há um despertar social para os impactos dessa mudança de hábitos, que gera implicações na saúde humana, na saúde do planeta e nos impactos socioeconômicos de várias populações. Isso, dado em função de alertas de organizações internacionais como, por exemplo, a Organização das Nações Unidas para a Alimentação e a Agricultura - FAO; do movimento Slow Food, que é de cunho internacional e sem fins lucrativos, agregando adeptos de vários países. Este despertar tem como princípio a valorização da comensalidade, a valorização da produção local, da cultura, da agricultura de base familiar e agroecológica, das cadeias curtas, enfim, da produção sustentável dos alimentos. Nesse sentido, é um movimento crítico à padronização alimentar em voga na sociedade globalizada, chamando à responsabilidade o consumidor de alimentos.

No Brasil, além desses dois órgãos citados acima, destaca-se também Fórum Brasileiro de Soberania e Segurança Alimentar - FBSSAN, que tem por objetivo promover a articulação entre pessoas, organizações, redes, movimentos sociais e instituições de ensino no intuito de buscar garantir a soberania alimentar e o Direito Humano à Alimentação Adequada (DHAA). Muito importante neste sentido também é a ação do Conselho Nacional de Segurança Alimentar e Nutricional - CONSEA, além de pesquisadores comprometidos com tais questões, na maioria deles, atuantes em grupos de pesquisa das universidades públicas e dos institutos de pesquisa. Um exemplo de ação conjunta no que se refere ao estímulo a uma alimentação de base mais natural e que promova a sustentabilidade socioambiental é o da equipe de trabalho que, em parceria com o Ministério da Saúde revisou e adaptou em 2014, o Guia Alimentar para a População Brasileira, distribuído gratuitamente no intuito de orientar os consumidores no processo de escolha. Dentre a amplitude preconizada pelo Guia, está o estímulo à aproximação com um sistema mais sustentável de produção e de consumo, e a crítica ao sistema de padronização alimentar e o formato de produção intensiva realizada pela agricultura de base convencional. Nesse sentido, chama a atenção, por exemplo, para a importância das cadeias curtas de comercialização, dentre elas, as feiras da agricultura familiar.

Este trabalho versa sobre as feiras, sobre as redes de sociabilidade e várias interfaces que a permeiam, tendo como casos estudados, as feiras que ocorrem nos municípios de Medianeira e de Marechal Cândido Rondon (MCR), na região Oeste do Paraná. $O$ interesse por realizar a pesquisa surgiu no sentido de compreender a existência e a resistência das feiras da agricultura familiar na região de estudo, na realidade contemporânea onde a monocultura da soja e do milho exercem forte influência na economia regional. As questões que nos instigaram a desenvolver a pesquisa foram: - $O$ que tem alimentado o interesse de agricultores e agricultoras familiares em permanecer cultivando para autoconsumo e comercialização de excedentes, e o que mantém a fidelidade do consumidor em frequentar as feiras, mesmo com as facilidades e praticidades dos espaços comerciais dos 
supermercados? Assim, o objetivo delineado para conduzir a pesquisa foi analisar e compreender as relações existentes entre agricultores-feirantes e consumidores no que se refere ao processo de comercialização, mas também às diversas outras interações possíveis, bem como, tecer comparações entre as dinâmicas das feiras, considerando a peculiaridade de cada uma delas.

Para conduzir este estudo, optamos por delineamentos voltados à pesquisa qualitativa no intuito de apreender as dinâmicas que ocorrem no ambiente da feira alimentar considerando a perspectiva das pessoas entrevistadas, bem como daquilo que foi observado durante a pesquisa de campo para então empreender a interpretação, a análise e a discussão.

Realizamos entrevistas semiestruturadas com 12 agricultores-feirantes e 10 consumidores em Marechal Cândido Rondon, e com 10 agricultores-feirantes e 10 consumidores em Medianeira. Usamos pseudônimos nos depoimentos e relatos para preservar a identidade dos interlocutores.

Os sujeitos da pesquisa dentro do ambiente das feiras foram escolhidos de maneira aleatória. A definição do número de entrevistas se deu em função daquela com menor número de agricultores participantes, no caso a de MCR, que possuía 17 gôndolas. Entretanto, algumas eram compostas por revendedores de produtos da agricultura familiar; dessa maneira, estipulamos 11 agricultores. Sendo a feira livre de Medianeira composta por 20 gôndolas, além dos agricultores representados pela Cooperativa da Agricultura Familiar e Solidária do Oeste do Paraná (COAFASO). O número definido para este município também foi de 11 agricultores feirantes, sendo 07 da feira livre associados à Associação de Produtores de Medianeira (APROME), e 04 representados pela COAFASO. Para manter uma simetria no número de entrevistas optamos por 11 consumidores em ambos os municípios.

$\mathrm{Na}$ análise das entrevistas recorremos à categorização, inferência, descrição e interpretação, não necessariamente nesta ordem. A linguagem possui importância fundamental sobre a noção da realidade que é pesquisada, pois por meio da relação entre interlocutor e entrevistado, num processo de interação entre os sujeitos, tornase mais interessante e analise dos aspectos socioculturais que permeiam a temática analisada, "através da análise de conteúdo, podemos caminhar na descoberta do que está por trás dos conteúdos manifestos, indo além das aparências do que está sendo comunicado" (MINAYO, 2016, p. 76). A pesquisa muito contribui para o entendimento da dinâmica das feiras nos dois municípios estudados, percebendo-se que além da venda de produtos mais saudáveis e frescos, este lugar traz consigo a oportunidade das conversas, do estreitamento de amizades, sendo uma rica aula de cultura, hábitos e tradições. Estudar como todos esses aspectos interagem em algumas feiras da região Oeste, pode representar uma contribuição importante no sentido de compreendê-las, não apenas como lugar de interseção entre o rural e o urbano - este limite tão tênue na contemporaneidade - mas também o encontro de identidades, conexões culturais e simbólicas.

Apresentaremos no item 2, a contextualização dos dois municípios analisados; no item 3, o perfil do público entrevistado; no item 4, a condução da pesquisa; no item 5, apresentamos a pesquisa de campo e a discussão realizada em uma abordagem etnográfica, onde utilizamos três categorias analíticas, a saber: agricultura familiar, ruralidades, segurança alimentar e sustentabilidade. Por fim, as considerações finais e as referências. 


\section{Contextualizando as feiras em Marechal Cândido Rondon e Medianeira}

Marechal Cândido Rondon e Medianeira, encontram-se localizados no Oeste do Paraná, região que se destaca por ser a maior produtora de soja do estado. Os municípios foram desmembrados de Foz do Iguaçu e foram colonizados, principalmente, por descendentes de imigrantes europeus, oriundos do Rio Grande do Sul e Santa Catarina.

As áreas de agricultura familiar diversificadas ainda resistem nos municípios, embora venham sofrendo redução ao longo dos anos, uma característica do Oeste do Paraná. Segundo Colognese, Gregory e Schallenberger (1999), Stoffel (2004), Colognese e Stoffel (2007), a agricultura familiar para autoconsumo e comercialização de excedentes na região Oeste do Paraná, inicia um processo de transformação na década de 1970, quando a produção local de alimentos tradicionais como arroz, feijão, batata e mandioca passa a ser substituída pela produção de soja e milho. Apesar dos problemas relativos à reprodução socioeconômica, isso não significou um abandono, extinção ou ruptura com a forma de produção tradicional anterior, mas em uma readaptação, que ainda hoje resiste em algumas propriedades por meio da produção de hortaliças, frutas, produtos de panificação, embutidos, ovos, hortifrúti em geral, mel, vinho, queijos, erva-mate, bolachas, melado, açúcarmascavo. Esses produtos são para o autoconsumo e o excedente é comercializado nas feiras locais.

No Oeste do Paraná, a agricultura familiar, apesar de toda a dinâmica de mudança agrícola que ocorre ao longo dos anos, como já apresentado, é uma característica importante no desenho territorial, sendo as feiras de agricultores muito frequentadas. Em Marechal Cândido Rondon e Medianeira, elas seguem em um "contramovimento" à direção que o desenvolvimento rural tem tomado nessas regiões em que há um forte incentivo à expansão do agronegócio da soja e do milho. Polanyi (2000, p. 98), define contramovimento como "um movimento bem estruturado para resistir aos efeitos perniciosos de uma economia controlada pelo mercado". É o que fazem os atores sociais de nossa pesquisa, ao resistirem às tantas contradições do capitalismo contemporâneo e se manterem no mercado de cadeias curtas com as suas gôndolas repletas de hortifrútis, produtos de panificação, doces, entre outros, ainda que produtos semelhantes estejam sendo oferecidos nos supermercados locais. De modo semelhante, os consumidores realizam 0 contramovimento ao serem assíduos e fieis a este tipo de mercado, que são as feiras.

\subsection{Marechal Cândido Rondon}

Neste município, a feira é composta por 17 famílias de produtores rurais, representados pela associação dos feirantes. Trata-se de uma associação civil de direito privado, sem fins lucrativos, organizada para a prestação de serviço aos seus associados, estabelecida em 10 de maio de 2001 (Figuras 1 e 2).

Figura 1. Espaço onde a feira é realizada em MCR, com suas diversas gôndolas 


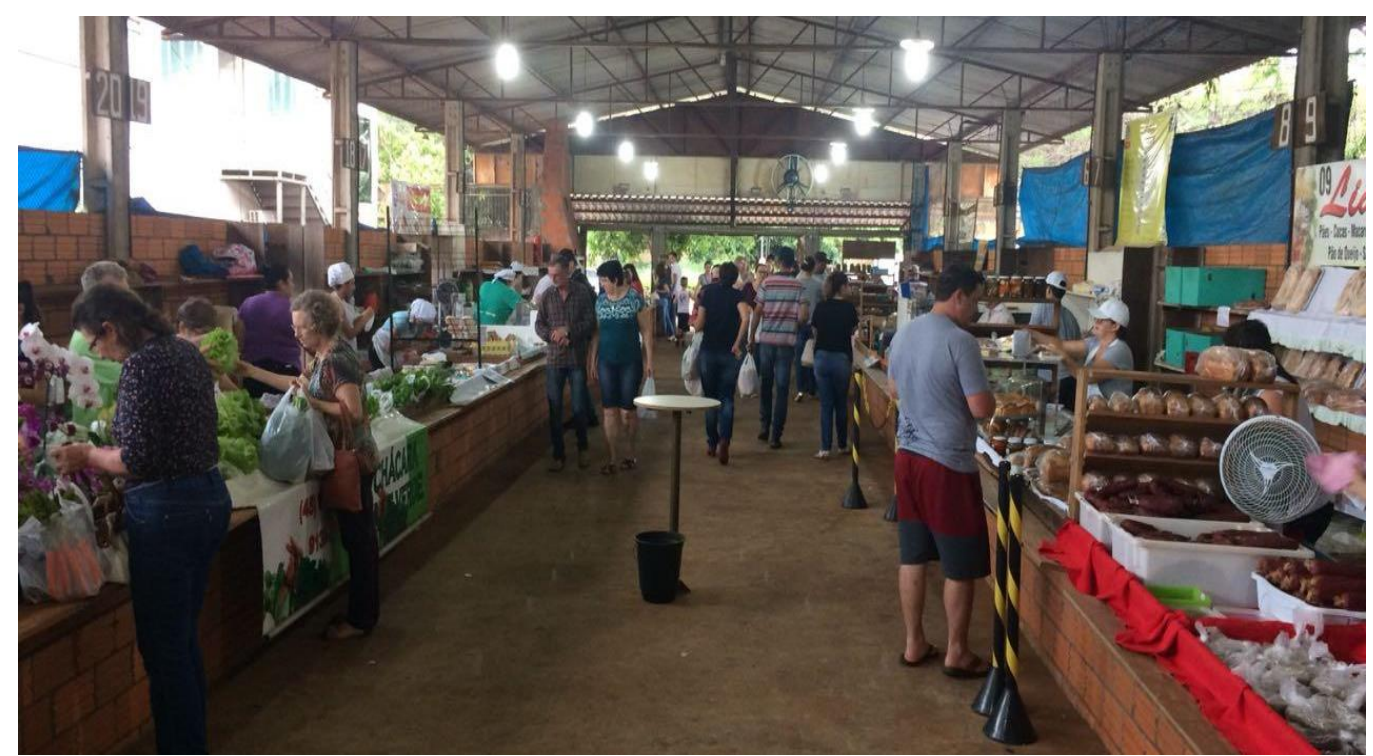

Fonte: pesquisa, 2018.

Antes mesmo de a Associação ser fundada e possuir um local próprio de comercialização, a feira acontecia ao ar livre na praça central. Em 2001, os agricultores conseguiram o terreno junto ao poder público. Ali foi construído o barracão onde acontece a feira atualmente.

Figura 2. Espaço onde a feira é realizada em MCR, com uma gôndola de embutidos

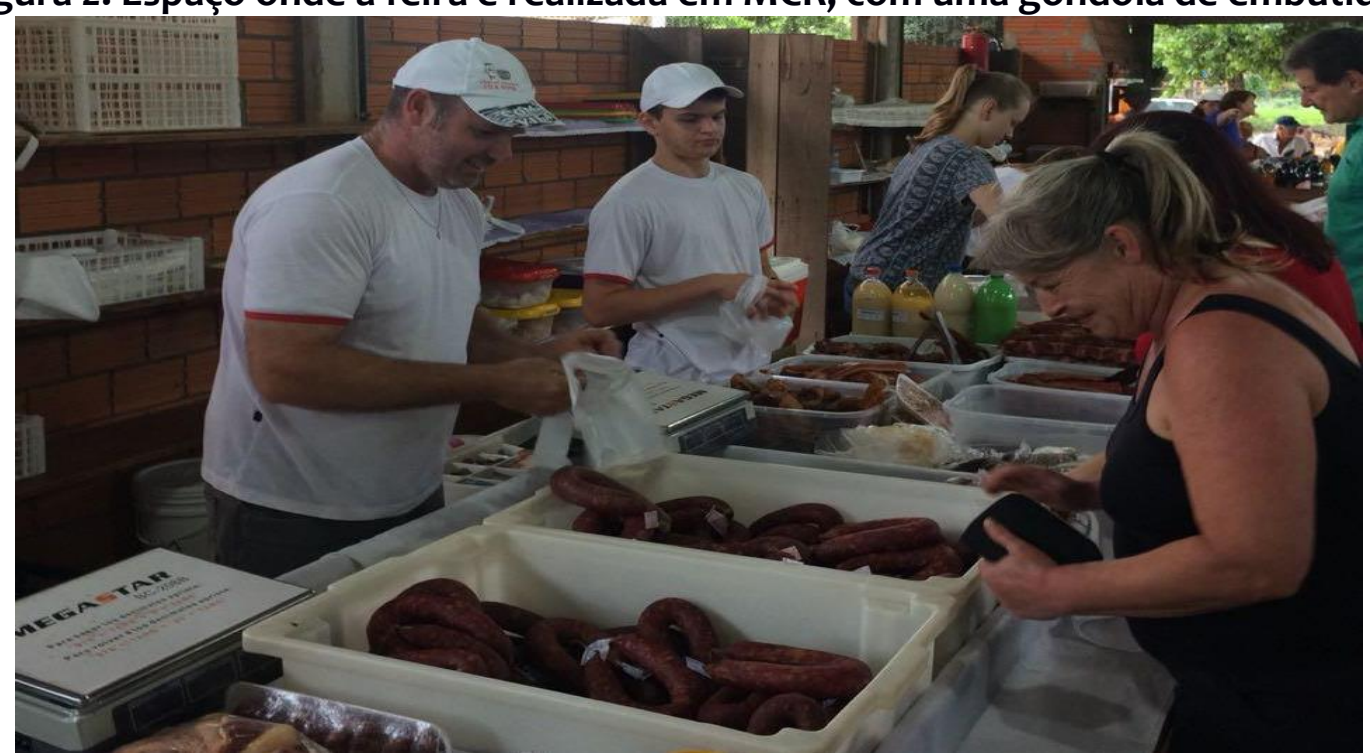

Fonte: Pesquisa de campo, 2018.

Para tornar-se um feirante é necessário associar-se, sendo admitidos apenas dois membros de cada família de produtores responsáveis por cada ponto de venda. Estas ações são registradas em cadastro próprio da associação, cujo nome dos membros também é devidamente arrolado. Em caso de mudança nos nomes dos responsáveis pelas bancas, estas alterações deverão ser comunicadas à diretoria e aprovadas em uma nova reunião, devidamente registradas.

\subsection{Medianeira}


Esse município destaca-se dos demais vizinhos pela liderança na formação e continuidade de associações formadas a partir dos agricultores familiares, ecológicos e orgânicos. A feira livre de Medianeira teve início no ano de 1985, com alguns poucos agricultores na praça central. Em 1996 foi fundada a associação, designada de 'Associação Feira do Pequeno Produtor Rural de Medianeira' - APROME. Desde 2009, a feira não mais acontece ao ar livre, mas, sim, na Casa do Produtor e teve seu início da junção de duas associações: a Associação dos Agricultores Familiares e Ecológicos de Medianeira - AAFEMED [Figura 3] e a Associação de Produtores de Medianeira - APROME [Figura 4]. Ambas tinham feiras em lugares distintos no município.

Figura 3. Casa do Produtor, Medianeira, espaço AAFEMED

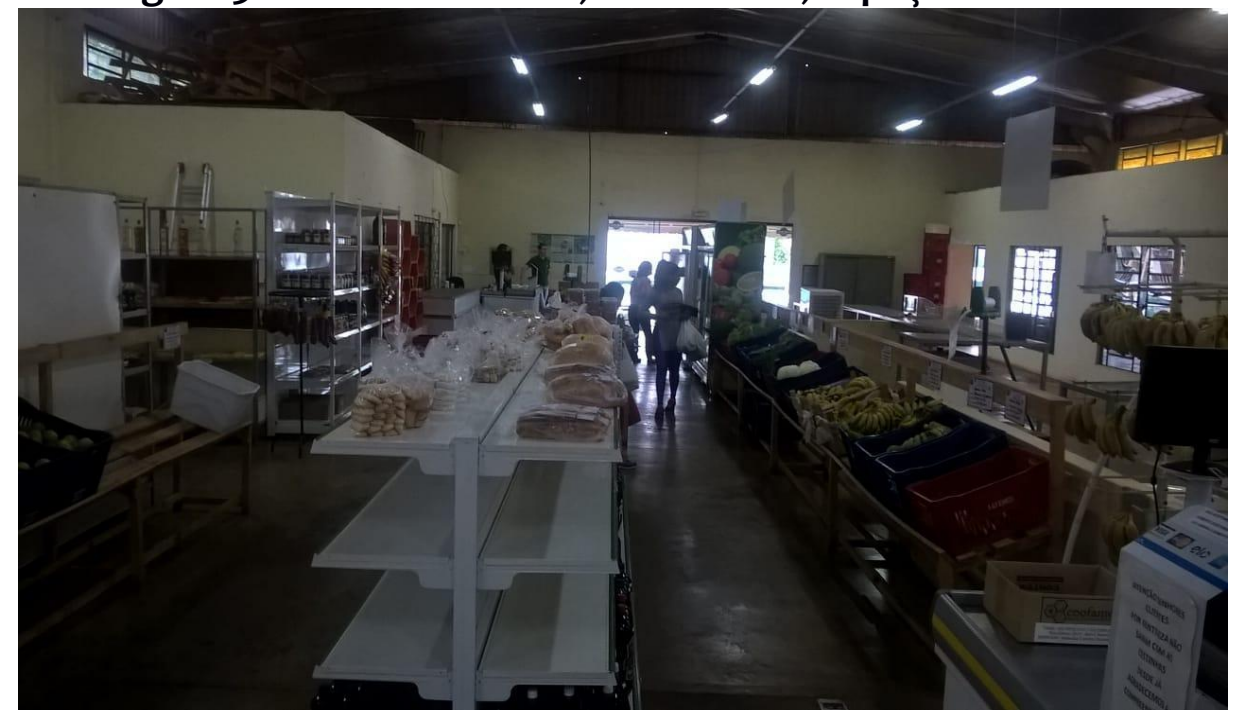

Fonte: Pesquisa de campo, 2018.

Figura 4. Casa do Produtor, Medianeira, espaço APROME

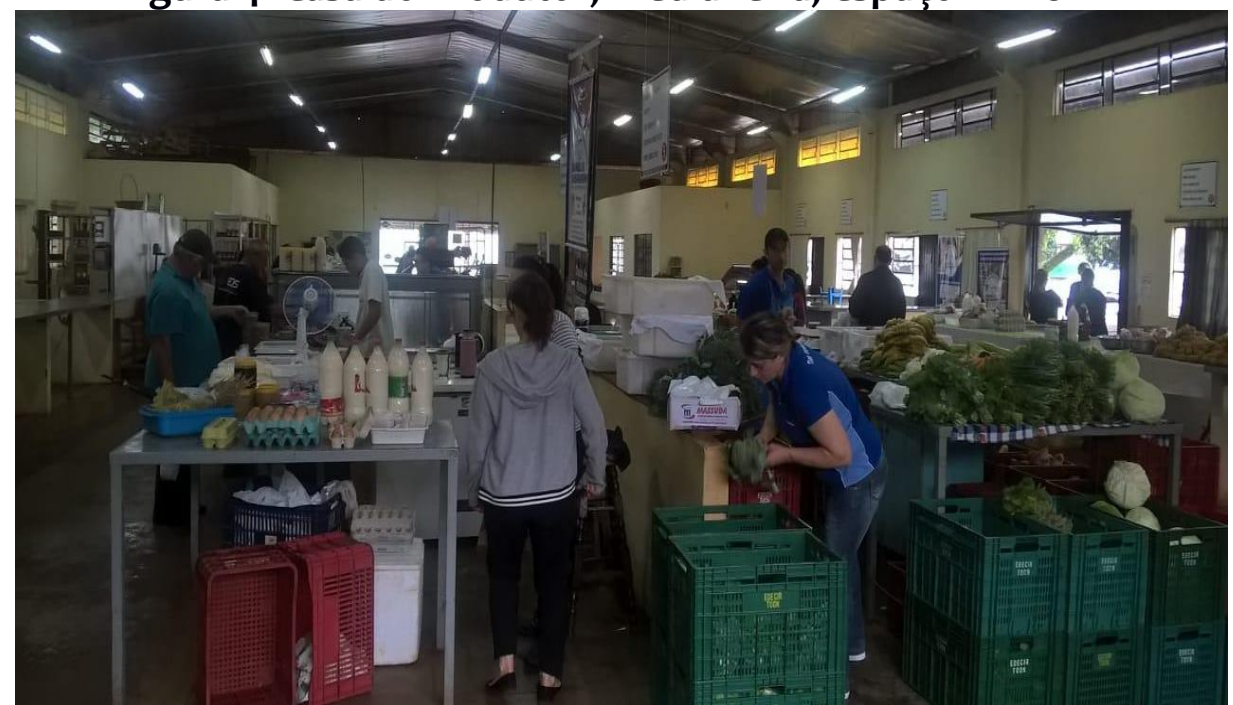

Fonte: pesquisa, 2018.

As sedes da APROME e uma das Unidades da Cooperativa Familiar Solidária do Oeste do Paraná (COAFASO) também estão localizadas na Casa do Produtor. Esta última iniciou o processo de comercialização em Medianeira em 2012 para tornar legal 
a venda dos produtos da AAFEMED e também proporcionar a entrada dos agricultores em uma das políticas públicas, que é a venda de produtos para a alimentação escolar, o Programa de Aquisição Alimentar (PAA), uma das políticas da Segurança Alimentar e Nutricional (SAN). A AAFEMED e COAFASO trabalham em conjunto. Alguns fatores, entre eles, a intensificação das vendas, foram importantes para que estas associações se unissem em prol da construção de um espaço em comum (COLOGNI, 2016).

\section{0 perfil do público entrevistado}

A agricultura familiar é muito representativa no Estado do Paraná. Do Censo Agropecuário de 1996 para o de 2006 os estabelecimentos da agricultura familiar não tiveram um aumento significativo, entretanto, dos 371.051 estabelecimentos rurais no Paraná, $80 \%$ correspondem aos dos agricultores familiares, ou seja, 302.902. A região Oeste do Paraná começou a ser ocupada e a receber seus primeiros imigrantes a partir de início de 1930, provenientes, principalmente, do Rio Grande do Sul. Segundo Rahmeier, (2016, p.46), "a base de colonização da região Oeste do Paraná foi de agricultores que tinham como objetivo a aquisição de terras na quantidade que pudessem produzir com a mão de obra familiar". Esse modelo fundiário permanece e se mantém até os dias atuais, pois nos municípios em estudo é uma das principais atividades econômicas exercidas.

As entrevistas realizadas com os agricultores-feirantes evidenciaram a mão de obra familiar, realizada principalmente pelo casal com o auxílio dos filhos $(81,81 \%)$ ou de alguns poucos funcionários (18,18\%). Esse aspecto é discutido em diferentes estudos sobre a agricultura familiar como em Veiga, et al. (2001), Abramovay (1992), Schneider (2010) e Schneider (2016).

Houve ainda o depoimento de uma viúva, que permaneceu na terra com a companhia do único filho, assumindo, assim, a responsabilidade pela propriedade. Outro depoimento marcante foi de um jovem, formado em Medicina Veterinária. Após a conclusão do curso, optou em permanecer na propriedade da família e, juntamente com os irmãos, conduzir uma agroindústria de laticínios. Casos como o do Felipe $^{2}$, não são regra na região estudada, pois entre os entrevistados apenas metade (50,00\%) possuem ajuda dos filhos, os demais, realizam as atividades em casal (31,81\%) ou com a participação de alguns funcionários (3 funcionários) (18,18\%).

A composição familiar é de 3,09 pessoas por família, incluindo os filhos menores de idade que apenas estudam ou aqueles que moram com os pais mas trabalham na cidade. Os agricultores feirantes do gênero masculino correspondem a $54,54 \%$; destes $27,27 \%$ têm entre 50 a 65 anos e os demais têm entre 30 a 49 anos. Já entre as mulheres na faixa etária de 50 a 80 anos temos uma porcentagem de 31,31\%; as demais agricultoras feirantes têm entre 33 a 49 anos (14,15\%). Observamos a pouca participação de jovens nas feiras, o que sinaliza para o que estudos discutem sobre o processo de envelhecimento e masculinização da população do campo. É o caso dos estudos de Camarano; Abramovay (1998), entre outros pesquisadores, que apontam que tal situação tende a aumentar, pois além da saída dos jovens rumo às cidades em

\footnotetext{
${ }^{2}$ Lembramos que, como explicado na introdução, os nomes aqui são fictícios, não correspondendo aos nomes reais das pessoas entrevistadas.
} 
busca de melhores condições ou de outras maneiras para sobreviver, as mulheres também participam deste movimento migratório. Lima (2015), identificou tal realidade também entre agricultores familiares da Zona da Mata de Minas Gerais.

Quanto aos consumidores entrevistados, percebeu-se que os jovens têm procurado adquirir diretamente do consumidor. Durante as entrevistas, observamos que entre os feirantes transitavam rapazes e moças jovens. Casais mais novos também procuravam por esses produtos, além de usarem a feira como local para lanchar. Em pesquisa conduzida por Paula; Scopel; Lima (2018), sobre as feiras de agricultores no município de Francisco Beltrão, Sudoeste do Paraná, a feira também aparece como local importante para lanches, não sendo raro o público que vai ao local apenas para se alimentar.

É possível afirmar por comparação que Marechal Cândido Rondon e Medianeira se assemelham em diferentes características, seja pela colonização, data de emancipação ou atividades econômicas. Nas áreas rurais essa semelhança também está presente, nas práticas alimentares e em alguns hábitos e costumes.

\section{A condução da pesquisa: o caminho percorrido}

A pesquisa de campo teve como objetivo analisar as relações existentes entre agricultores-feirantes e consumidores, no que se refere ao processo de comercialização, mas também das diversas outras interações possíveis, da simbologia, cultura, tradições, identidades e práticas alimentares, assim como a confiança estabelecida entre os atores envolvidos, observando e tecendo possíveis análises sobre os aspectos e dinâmicas ocorrentes entre as feiras em estudo.

Sobre a simbologia, cultura e tradições, o interesse foi o de saber se alguns dos alimentos adquiridos e vendidos nas feiras traziam lembranças da infância e/ou juventude, se parte daquele espaço remonta um passado, imagens e pessoas. Além da faixa etária aproximada de todos entrevistados, perguntou-se aos agricultores feirantes há quanto tempo moram no mesmo sítio da região pesquisada. Quanto à identidade e as práticas alimentares, a investigação consistiu na produção e suas caraterísticas tipológicas, ou seja, de que maneira essa produção é realizada (orgânica, agroecológica ou tradicional); em quais locais se realiza o escoamento da produção; como e quando é o preparo para fazer a feira, incluindo aqui o sentimento de valorização e sentimento de realização dos agricultores quanto à atividade desempenhada.

Em relação aos consumidores, o interesse foi relacionado ao tempo em que é cliente da feira; o que adquirem e porque; se sabem como são produzidos os alimentos ali comercializados; e se consideram importante contribuir com a agricultura familiar fazendo compras nas feiras.

\section{A pesquisa de campo - discussão em uma abordagem etnográfica}

O planejamento de um projeto, bem como o transcorrer de suas etapas tem na pesquisa de campo, a etapa mais importante. O primeiro contato, os primeiros olhares, como iniciar, são dificuldades e desafios que são desvencilhados aos poucos. Lidar com o público mesmo que em instâncias pequenas, não significa facilidade em obter o esperado. Abordar pessoas estranhas e convidá-las a participar de uma 
entrevista requer ao menos empatia, alteridade, para assim começarmos uma longa jornada.

Dos comprimentos ao muito obrigado final, delimita-se uma relação com o entrevistado. Durante a entrevista, é possível vivenciar diferentes sentimentos em decorrência da ênfase dada pelo locutor. Pessoas que ao serem interrogadas, buscam em suas memórias lembranças até então esquecidas, ou melhor, em stand by, vem à tona recordações do passado em família, dos modos de viver, lembranças trazidas por cheiros e sabores. Já para outras pessoas entrevistadas, essas lembranças não são expostas com intensidade, pessoas diferentes, lembranças e percepções diferentes.

Ao longo dos meses em que a pesquisa de campo se estendeu muitas pessoas quando abordadas, não dispunham do tempo para participar da entrevista. O tempo, esse que rege e administra nossos dias, que dita regras e nos faz adaptar todo o possível em sua função, seja o trabalho, o estudo, a família, os relacionamentos. Tornamo-nos reféns do tempo que nós mesmos criamos. Assim como para Harvey (2015), compreender o tempo e o espaço como formas da representação da vida social, faz com que as pessoas ( $\mathrm{re}$ ) produzam diferentes sentimentos, tornando os espaços individualizados conforme suas experiências.

Tal percepção, o feeling, tão necessário a quem pesquisa, permitiu a obtenção de um rico material envolvendo diferentes olhares e interpretações. Os sentimentos e as percepções para ambos os atores da pesquisa, bem como a importância do "fazer a feira", para o consumidor, são desmembrados no texto, em categorias, no intuito de facilitar a leitura e compreensão, assim como transmitir os significados e símbolos dessa comunicação direta entre entrevistador e entrevistado. Para Carvalho e Souza (2013, p. 14) a organização de um trabalho de dados de pesquisa "deve ser apreendida como uma relação cujos elementos são acomodados em seus devidos espaços por causa de suas características formais".

Neste sentido, as categorias elencadas são: agricultura familiar (produtividade, comercialização, redes de sociabilidade), ruralidades e segurança alimentar e sustentabilidade. Em cada uma dessas categorias é realizada uma breve discussão teórica que são entrelaçadas com as falas dos interlocutores.

\subsection{Categoria 1: agricultura familiar}

Justamente nesses espaços individualizados e carregados de simbologias, as feiras livres, objeto deste estudo, transformam e agregam os saberes e fazeres ali incutidos. Mais do que espaço comercial, onde os agricultores veem seus produtos 'transformarem-se' em renda, as feiras são lugares de vivências sociais, culturais e que podem representar, segundo Pereira; Brito; Pereira (2017), 'um lugar de preservação dos aspectos peculiares ao ambiente rural, da autonomia do (da) agricultor (a) e do fortalecimento dos laços e do saber local'. Ainda segundo os autores, os agricultores familiares, comercializam seus produtos, além de seus conhecimentos, cultura e identidade.

[...] proporciona oportunidades de abastecimento com produtos de características locais, além de baratos e saudáveis, garantindo a soberania e a segurança alimentar, pois o consumidor sabe onde e como os alimentos foram produzidos e a segurança é garantida no valor acessível, na 
diversidade e no uso quase que nulo de agrotóxicos, o que serve como um impulsionador da agricultura familiar e o desenvolvimento rural em bases sustentáveis (PEREIRA; BRITO; PEREIRA, 2017, p. 68).

Enfatizando a fala do autor de como os agricultores se sentem importantes, pois produzem e vendem com qualidade, dona Maria, agricultora e feirante, de 56 anos, deixa isso evidente em sua fala:

Porque o nosso produto é de qualidade, a gente procura sempre oferecer o melhor; o frango é inspecionado acompanhado por veterinário, eu não tenho medo de vender (D. Maria, 56 anos, Marechal).

Há uma constante preocupação com a qualidade final do produto, pois o desejo é receber elogio de quem o adquire, e que sempre volte em outros dias de feira. Felipe, agricultor de 32 anos de idade, comercializa produtos de seu laticínio de administração familiar. Ele nos diz que:

Todo mundo quer comer coisas boas, então a gente traz o melhor prá feira, para tentar agradar o nosso cliente (Felipe, 32 anos, Medianeira).

As feiras livres podem ser analisadas de diferentes maneiras. Trazemos aqui tanto o olhar do feirante agricultor, como o do freguês. Observamos que para ambos os atores as feiras possuem importante papel na valorização de bens imateriais (social, cultural) além de contribuir para a economia local e regional. Por seu tempo de perpetuação histórica e cultural é possível considerá-las como espaço e lugar de resistência e de adaptação de fragmentos da sociedade, advindos de relações do passado, mas que permanecem existindo no presente.

Nesse contexto, observamos os diferentes olhares dos consumidores sobre quem vem a ser a agricultura familiar:

É um trabalho desenvolvido em família dentro da pequena ou média propriedade. As pessoas do grupo familiar desenvolvem um rendimento sustentável como tem vários agricultores aqui (Mateus, 45 anos, Medianeira);

É a agricultura tocada pelos membros da família (Marta, 30 anos, Marechal);

É quem trabalha com a mão-de-obra da família na agricultura (Pedro, 54 anos, Marechal).

Muitos dos entrevistados não sabiam o significado de agricultura familiar. Outros apenas associavam a algum tipo de programa do governo. Entretanto, quando perguntados se consideravam importante contribuir com esse tipo agricultura, adquirindo seus produtos originários, a resposta afirmativa foi unânime:

Eu acho que gente precisa valorizar porque é o sustento deles. (Lurdes, 63 anos, Medianeira); 
Na minha opinião, eu acho que é importante demais! Porque, primeiro, eu estou comprando uma coisa mais natural, mais saudável e o dinheiro já vai ficar aqui mesmo, não vai pra fora. (Marcos, 59 anos, Marechal);

Eles se mantem assim... se a gente não valorizar, eles acabam, a feira acaba (Silvia, 33 anos, Medianeira).

As feiras livres da agricultura familiar possuem ainda papel central na geração de renda para as famílias agricultoras. No caso dos nossos interlocutores, isso foi registrado como um dos pontos muito importantes para permanecer na atividade desse tipo de comercialização. Situação semelhante foi observada na pesquisa de Paula; Scopel; Lima (2018), desenvolvida com agricultores feirantes em Francisco Beltrão, Paraná; na de Ângulo (2003), no Vale do Jequitinhonha, Minas Gerais, e na de Roberto, et al. (2018), em Alegre, Espírito Santo. Em alguns casos, a renda propiciada pelas feiras representa a fonte principal para muitas famílias de agricultores, como o que foi observado por Gastal et. Al. (2016), em Unaí, Minas Gerais.

Se a feira tem importância fundamental para as famílias agricultoras como reprodução econômica, ela é também, por consequência, um instrumento que permite a manutenção de muitas dessas famílias na atividade rural, insistindo, apesar das dificuldades encontradas de levar sua produção até as pessoas que habitam as cidades e oferecer-lhes uma alternativa de aquisição alimentar.

Assim, as feiras são constituídas de complexidades que as tornam tão resistentes pelos diversos lugares do mundo. Para Araújo e Ribeiro (2018, p. 305), “o espaço na qual o agricultor familiar fica inserido vai além das concepções econômicas, tem importância no desenvolvimento territorial, visto sua alta capacidade de produzir ocupações, renda e qualidade de vida".

\subsection{Categoria 2. Ruralidades}

Sendo esta pesquisa pautada e transcorrida da agricultura familiar, achamos interessante trabalhar a ruralidade como uma das categorias. Sabe-se que o termo 'agricultura familiar' foi empregado tardiamente no Brasil, visto de forma inicialmente consolidada nos finais dos anos 1980. Schneider (2003, p. 14-15), esclarece o emprego do vocabulário, de forma a entender como:

\footnotetext{
"[...] a chegada tardia das discussões e pesquisas sobre a agricultura familiar no Brasil pode ser entendida com base na identificação dos referenciais teóricos que inspiraram boa parte dos estudiosos, fortemente influenciados por aportes analíticos que mantiveram um excessivo apego às formulações clássicas em torno do problema agrário nacional e dos processos de formação e luta de classes sociais no campo".
}

Em consonância com o autor acima, Wanderley (1996, p. 02) explica que a agricultura familiar 
familiar como novo personagem, diferente do camponês tradicional, que teria assumido sua condição de produtor moderno; propõem-se políticas para estimulá-los fundadas em tipologias que se baseiam em uma viabilidade econômica e social diferenciada [...]".

Carneiro (2005), é crítica do pensamento sobre o rural centrado no distanciamento ou oposição em relação ao urbano sem considerar as demais dimensões que este espaço consegue dar conta de entrelaçar de forma dinâmica. Nesse sentido, Carneiro (1998, p.1 apud Lima; Neto; Farias 2016.p. 70) analisa que:

\footnotetext{
Compreender o dinamismo que ocorre no campo é importante, no sentido de não congelar o conceito de rural como uma categoria imutável ou o lugar da incapacidade de 'absorver e de acompanhar a dinâmica da sociedade em que se insere e de se adaptar às novas estruturas, sem, contudo, abrir mão de valores, visão de mundo e formas de organização social definidas em contextos sociohistóricos específicos'.
}

Nesse sentido de dinamismo, tanto Carneiro (2005 e 1998), como Wanderley (2000), tratam da importância do pensamento do "novo rural", que é aquele que vem absorvendo as mudanças ocorridas na sociedade mais ampla, desde que essas mudanças sejam interessantes ao rural; absorve e adota características dos tempos modernos, sem romper definitivamente com alguns modos tradicionais de reprodução social e cultural. Para Medeiros (2017, p.181) "as atividades socioeconômicas se modificam, as paisagens se transformam, a gestão do território muda, a distribuição do povoamento se altera assim como, as relações de vizinhança".

Segundo Brandemburg (2010), pode-se falar da existência de rurais localizados em tempos diferentes no Brasil, mas estes "persistem, ora na sua forma típica, ora sobrepostos, ora expressos na forma de um rural novo, reconstruído ou reflexivo" (Brandemburg, 2010, p. 423). E, para Wanderley (2000) há dois fatores importantes que marcam esse dinamismo da agricultura familiar e eles passam pelo reforço que as políticas públicas, como o Pronaf a partir da década de 1990, e outras posteriores, exerceram na constituição dessas mudanças. Para a autora, as feiras da agricultura que ocorrem nas áreas urbanas representam um dos importantes mecanismos de comercialização para as famílias agricultoras e fortemente responsável pela permanência de muitas delas nas áreas rurais, considerando ter nesse tipo de comercialização um aporte de renda fundamental.

A pesquisa que realizamos com os agricultores feirantes e consumidores de seus produtos, tem nos apontado muitos aspectos dessas ruralidades. Da parte dos nossos interlocutores, participar de mercados alternativos como as feiras livres, que estão inseridas nas redes curtas; a intenção de permanecer produzindo em pequena escala, mas com diversidade e qualidade; é uma forma de adaptar-se e reinventar-se todos os dias.

Dona Amanda, de 80 anos, nossa interlocutora com mais idade foi a que demonstrou mais relação afetiva em atuar na feira. Uma mulher que nos pareceu muito saudável, demonstrando motivação para a lida diária no campo, nos apontou para os vidros de chimia e disse: "Olhe isso, fui eu quem fez"! 
[...] é bom de vim, para mim é muito, muito bom de vim, senão com 80 anos eu não vinha mais, as vezes eu fico ruim lá e só espero a sexta para vim na feira...para mim é um remédio. (Amanda, 80 anos, agricultora feirante, Medianeira/PR).

Na fala de Carlos, 54 anos, também percebemos o significado de estar ali comercializando, conquistando fregueses em função da confiança que vai se estabelecendo e conferindo credibilidade a seus produtos:

\begin{abstract}
Eu tenho muitos fregueses certos. Eu acho aqui muito bom, porque a gente conversa direto com eles, eles perguntam como produzir em casa, o que você me indica para tal coisa, eu passo porque é cliente, amigo... aqui é um lugar de venda e um lugar legal, aqui você encontra cliente, amigo, conversa, tem os companheiros de trabalho é muito bom, você faz mais amizade né, até os amigos dos amigos se encontram, fica conversando, rever as pessoas é muito bom. Aqui as pessoas vem atrás do que gosta, vem buscar sua bolacha, seu salame, vem buscar uma salada, vem comer um pastel, vem pegar o melado que sabe né, a gente aqui consegue vender mais barato do que o mercado, e é uma coisa que não tem química, não tem conservante, não é industrializado, nada, é um produto que faz toda semana, que a gente traz fresquinho, mesmo a chimia que a gente faz, é feito só na pressão, que veda e pode ficar até dois anos que não vai estraga (Carlos, 54 anos, agricultor feirante, Marechal/PR).
\end{abstract}

Outro ponto importante a destacar é a presença feminina. Elas se identificam como agricultoras, falam orgulhosamente sobre o seu trabalho no campo, seja plantando, colhendo, administrando propriedades, além dos afazeres domésticos, que ainda permanecem sob a responsabilidade delas.

A agricultura familiar tem se fortalecido com a participação e o empoderamento feminino. Nascimento (2018, p.1) considera a atuação da mulher como avanço para o desenvolvimento da agricultura familiar, pois "as mulheres, cada dia mais, são essenciais nas transformações que visam o desenvolvimento no campo. Elas estruturam as famílias rurais e acolhem como ninguém, a causa da sustentabilidade".

As mulheres eram maioria dentre os que responderam às nossas entrevistas, não por seleção prévia, mas por serem o maior público presente nas feiras nos momentos da pesquisa e as que se prontificaram a responder sem resistência, tanto entre o público feirante quanto consumidor. Para algumas agricultoras o trabalho da feira faz parte de suas vidas há muitos anos e foram aos poucos compreendendo como lidar com essa atividade. É o caso de Rafaela, de Medianeira, que explica que toda a produção do sítio que é levada para a feira é vendida, raramente retorna com algum produto para casa.

Comecei a produzir para entrar na feira, com derivados de porco, mas isso há 30 anos atrás, depois foi passando o tempo e descobrimos que as coisas que tinha lá (no sítio) poderia ser vendida, porque desperdiçar lá é pior, ai começou entrar outras coisas, porque tudo aqui na feira vende, porque tem esse padrão de dizer que as coisas do interior é melhor, e é melhor mesmo (Rafaela, 56 anos, agricultora feirante, Medianeira/PR). 
Fernanda, 48 anos, agricultora em Marechal/PR, faz feira há 20 anos e relatou sentir muito orgulho disso.

Ah... é gostoso! É um amor que a gente sente, sabe...quando cai um feriado que a gente não pode vir, faz uma falta; além disso tem os troquinhos, né?

Para Catarina, 61 anos, agricultora em Medianeira/PR, fazer feira é um passeio:

Sinto falta quando não venho, apesar de que não falto, gosto muito de vim, não só pela venda como pela conversa, para mim é um passeio.

No que se refere aos consumidores, a feira parece reassumir um papel relevante na contemporaneidade. A angústia alimentar vivida, sobretudo, pelos consumidores urbanos em relação às suas escolhas e diante do risco alimentar da ingestão de vegetais contaminados por agrotóxicos, tem feito das feiras de agricultores, principalmente daquelas denominadas como orgânicas e, ou, agroecológicas, um lugar de esperança para se adquirir alimentos saudáveis, produzidos de forma mais sustentável, embora nem sempre os preços sejam inferiores aos dos supermercados.

\footnotetext{
Muitas pessoas reclamam que aqui alguns preços são mais altos do que no supermercado, mais aqui é mais natural, eu sei que é difícil produzir. Eu acho justo e pagaria mais se fosse orgânico, porque é o melhor para a minha saúde, se eu invisto muito melhor na minha saúde eu gasto menos lá na frente (Francisco, 57 anos, consumidor de Marechal, PR, 2017).

Faz muitos anos que eu frequento feira, e quando eu viajo eu costumo visitar as de onde estou, eu tenho esse perfil de valorizar a agricultura familiar (Janete, 47 anos, consumidora em Medianeira, PR, 2017).
}

Nesse sistema de relações entre o consumidor e o agricultor-feirante vão se estabelecendo redes de confiança, onde forma-se a "freguesia" e a barraca de preferência. Pois como defendido por Granovetter (2007, p. 13), "as relações sociais, mais do que dispositivos institucionais ou de moralidade generalizada, são as principais responsáveis pela produção de confiança na vida econômica”.

Certamente são mais saudáveis, normalmente se conhece a origem, e se acompanha a produção deles de certa forma, isso da mais confiabilidade no consumo (Maurício, 62 anos, consumidor em Marechal Cândido Rondon, PR, 2017).

Eu compro de todos, mas eu sou freguês de duas barracas especificas a do Guilherme que faz massas, e produtos diferenciados, bolo de banana, mandioca...a massa do pastel dele que é muito boa, e a do Moacir, eles produzem verduras, batata doce, eles assam a batata doce (Mateus, 45 anos, consumidor em Medianeira, PR, 2017).

Sou freguesa só não sei os nomes. Essa relação mais próxima com o agricultor é mais direto, da de confiar nas coisas, sabe como ele faz, como produz, que é limpo (Silvia, 33 anos, consumidora em Medianeira, PR, 2017). 
Muito mais do que o ganho econômico, as feiras significam para os agricultores familiares liberdade e autonomia sobre sua produção. Poder vender e negociar suas mercadorias diretamente com os consumidores têm relevância em diferentes aspectos.

As feiras compõem as chamadas cadeias curtas que, como já visto, representam uma forma de mercado alternativo, proporcionando aproximação entre o agricultor e o consumidor. Essa aproximação vai além do espaço, forma uma interação onde ambas as partes se conectam e trocam informações, conhecimentos e saberes que cada alimento pode oferecer. Esses mercados alternativos estão se diversificando nos dias atuais. Além das feiras livres e casa do produtor, tem-se a entrega de cestas semanais com diferentes produtos, desde o hortifrutigranjeiro a misturas (massas, pães, bolachas), a venda de produtos de casa em casa, que também estão ganhando espaço no cotidiano.

Muitos agricultores e agricultoras mais articulados conseguem perceber a importância de sua atividade como produtores de alimentos e as inter-relações que existem nesse processo agroalimentar no que se refere inclusive à sustentabilidade alimentar e produtiva. Embora não conheçam as teorias, dominam o engenhoso raciocínio de quem precisa fazer perpetuar sua atividade, como nos mostra o depoimento de um entrevistado:

\footnotetext{
Eu acho a feira a principal janela, o que a gente precisa é conscientizar o povo que o produto da feira quem sabe não é o mais bonito, a fruta a verdura, mas ele é mais saudável, entendeu, então é isso que a gente tem que divulgar. Mas eu acredito que essa proximidade é o futuro, todo mundo quer comer coisas boas, então a gente traz o melhor pra feira, para tentar agradar o nosso cliente (Felipe, 32 anos, agricultor e associado da AAFEMED, Medianeira, PR, 2017).
}

Felipe tem uma história interessante, apesar de não ser assunto de discussão específica dessa pesquisa. Compreendemos o quanto a permanência dos filhos ou o retorno após conclusão dos estudos pode fortalecer o desenvolvimento rural. Felipe saiu de casa para estudar veterinária. Ao concluir o curso decidiu voltar para a casa dos pais. Empregando seu conhecimento da graduação, convenceu os pais e os irmãos da importância de investir em melhorias para o sítio começando pelas vacas leiteiras, já que delas retirava-se o sustento, na época leite para entregar no laticínio. Atualmente, a família de Felipe possui uma agroindústria de produtos derivados do leite, como queijos, iogurtes, nata, manteiga, produtos estes que abastecem feiras e mercados de Santa Helena e região, como Medianeira e Foz do Iguaçu.

A importância da feira para a maioria dos agricultores entrevistados é muito mais profunda e complexa do que se pode observar nesses espaços. Para muitos, a feira significa a renda principal da família, ou uma das mais importantes. É uma lida diária aprendida desde muito cedo, já na infância, práticas repassadas entre as gerações, algo que muitos livros não ensinam, mas que tem sua impressão marcada nas mãos, nos rostos e na alma destes agricultores. Não como sofrimento, desespero ou a única saída, mas sim como amor pelo que fazem e orgulho de ser quem são, mesmo enfrentando algumas formas de preconceito, como relatado a seguir por uma das entrevistadas: 
Me sinto valorizada, também, algumas pessoas até hoje dizem 'ah...porque é 'colona', mas isso existe e sempre existiu, mas você gostando do que faz é o que importa, é só fazer com amor e carinho que tudo dá certo (Samara, 49 anos, agricultora em Marechal Cândido Rondon, PR, 2017).

A feira entrou nas nossas vidas no momento de necessidade mesmo, porque a gente vivia só da lavoura, ai procuramos alguma coisa como uma renda extra, aí apareceu a feira, há 18 anos e meio que a gente faz feira e hoje é um dos carro chefe (Samara, 49 anos, agricultora em Marechal Cândido Rondon, PR, 2017).

Há já faz muitos anos que faço feira. A gente já trabalhava com feira antes de vir para este município, no município de Missal, depois a gente começou aqui, desde o início da feira a gente está participando [...] as duas coisas, porque a gente produz quando sabe que vai vender. [...] e claro, isto satisfaz, porque caso contrário a gente nem estaria mais na agricultura (Antonio, 65 anos, agricultor e associado da AAFEMED, Medianeira, PR, 2017).

Esses e outros relatos coletados na pesquisa, nos ajudaram a perceber o quanto a feira significa para os agricultores familiares, mesmo que as dificuldades estejam presentes. Muitos disseram notar pouca valorização por parte do poder público das atividades - tanto da feira, quanto da agricultura. O resistir e o persistir, não apenas com as feiras, mas com a pequena produção de alimentos em uma região onde a monocultura da soja avança rapidamente, é uma maneira clara e explícita de querer continuar a se reproduzir social e economicamente na sociedade contemporânea, e, por meio do que produzem, se fazer presentes na mesa de diferentes pessoas ao mesmo tempo.

A seguir, alguns depoimentos de consumidores descrevem a feira como um espaço agradável e com características peculiares. Adquirir ali, produtos que antes, na maioria das vezes, eram comprados em supermercados, traz ganho ao comprador e ao vendedor, pois é uma forma de valorizar o trabalho do agricultor, comprando direto de quem produziu, adquirindo informações sobre o produto e a forma de produção, e, recordando, muitas vezes, da infância e juventude, o que está atrelado à memória afetiva.

Tenho lembranças da infância sim, porque na verdade eu vim da agricultura, meus pais eram agricultores, então, depois eu vim morar na cidade...mas se eu pudesse voltar para a agricultura, eu voltaria, porque eu adoro, o campo é mais saudável que a cidade (Leticia, 57 anos, consumidora em Marechal Cândido Rondon, PR, 2017).

Acho importante vir a feira, comprando aqui certamente, estou incentivando a continuidade desse sistema (Maurício, 62 anos, consumidor em Marechal Cândido Rondon, PR, 2017).

A nata não industrializada lembra minha infância que a gente comia essa nata, o pé de moleque [...] eu acho que o governo federal e os municipais deveriam dar muitos mais incentivos, porque ainda falta (Janete, 47 anos, consumidora em Medianeira, PR, 2017). 


\begin{abstract}
Eu acho que as pessoas do centro urbano hoje estão ligadas na tecnologia dos celulares, computadores...o filho do país hoje é a agricultura. O país é isso, por exemplo: esse celular seu, talvez a gente nunca consiga produzir, mas nós temos a agricultura, então acho que temos que investir nas máquinas para a agricultura, porque elas são caras e são produzidas fora, então deveríamos produzir aqui para ser mais barato ao agricultor, porque o que vamos exportar para fora é o produto da agricultura, é a comida. E o país deveria conseguir a reforma agraria, pois tem muita concentração de latifundiário, é muita terra para pouca gente (Manuela, 67 anos, consumidora em Medianeira, PR, 2017).
\end{abstract}

A confiança é outro fator que atrai o consumidor, mesmo que alguns agricultores não tenham selo de certificação de orgânico ou o do Serviço de Inspeção do Paraná (SIP). Para os consumidores, os produtos ofertados nas feiras têm mais qualidade, são mais confiáveis do que aqueles comercializados em supermercados. Umas das justificativas dadas é que a família agricultora comercializa neste espaço os mesmos produtos que consomem e isso gera uma relação de confiança muito importante para os consumidores que entrevistamos

\begin{abstract}
Aqui tudo que tem é bom, é artesanal, é da agricultura, que nem esse queijo colonial, isso aqui não tem lá no Rio, eu nem sei como que fazem, cada um tem um sabor, uma mistura, cada um de uma região, um do alemão outro do italiano, uma coisa que achei aqui é o capricho, as pessoas fazem tudo com muito capricho, e você sabe que está levando uma coisa 100\% daquilo que se está vendendo, que se propõe, se você compra leite, você sabe que é puro, que ninguém colocou água, misturou alguma coisa, isso dá credibilidade (Manuela, 67 anos, carioca, morando em Medianeira há 3 anos)
\end{abstract}

Eu gosto dos produtos das pessoas que trazem da roça, porque às vezes a gente vai no mercado e pode ser que tenha mais agrotóxico, que venha de fora, eu gosto de valorizar o pessoal daqui. Porque a nossa a região aqui ela é baseada na agricultura, a gente tem que aprender a valorizar o pessoal daqui pra trazer os produtos daqui. Até teve uma época em que queriam fechar e eu falei: - Nossa é uma perda inestimável, porque o pessoal vem, expõe os produtos deles, não é porque tem etiqueta, que o produto é melhor que o daqui, claro que tem as orientações de higiene, mas eu nunca tive problema com produto nenhum daqui que eu comprei, são todos de excelente qualidade, o pessoal atende com muito carinho, e uma coisa que eu fico sentida, as pessoas às vezes falam: - Nossa, você pagou dois reais nesse pezinho de alface? Ai eu falo: - Mas você viu como estava o clima, você viu se o clima ajudou, o pessoal foi lá, plantou, a gente que já fez parte disso já sabe o que é (Valéria, 38 anos, consumidora, Medianeira/PR).

As falas acima demonstram uma valorização dos produtos que vêm do campo, mas também da cultura rural, dos modos de fazer, contidos na elaboração desses produtos. Na primeira fala, a de Manuela, está presente um olhar - talvez até romantizado por estar habituada a uma vida numa capital. Em sua percepção sobre o interior e os agricultores, tudo é perfeito, e destaca o aspecto da honestidade: "se você compra leite, você sabe que é puro, que ninguém colocou água, misturou alguma coisa, isso dá credibilidade". O leite é comercializado em garrafas PET. 
Observamos, pelos depoimentos, o peso positivo das interações sociais que se criam entre os atores, estabelecendo normas de condutas pessoais que são também comerciais. Isso permite manter essas teias sociais e comerciais que vão contribuindo para legitimar as feiras como lugares centrais no que se refere às redes curtas dos municípios envolvidos. As falas estão recheadas de adornos que caracterizam a ruralidade, esse espaço repleto de humanidade, de histórias e de tradições pinceladas de modernidade.

\subsection{Categoria 3 - Segurança alimentar e sustentabilidade}

No que tange à segurança alimentar e nutricional, soberania e sustentabilidade, as feiras representam importante espaço de interface. Segurança alimentar e nutricional, em função de, a priori, as feiras comercializarem produtos de um tipo de agricultura onde utiliza-se maior controle de produtos agrotóxicos, ou nenhum, sobretudo, porque os agricultores comercializam o excedente, ou seja, consomem quase sempre o que produzem. Mas são as relações de confiabilidade que fazem os consumidores adquirirem produtos sem certificação acreditando serem eles livres de agrotóxicos.

Assim, parte-se do princípio de que a preocupação com a saúde da família além de uma cultura que envolve uma relação mais próxima com a produção dos alimentos que consomem - garante minimamente um alimento de melhor qualidade, inclusive, nutricionalmente, ao manifestarem preocupação com as boas práticas de produção agrícola. Alguns dos agricultores feirantes disseram realizar cursos de extensão para melhorar a produção. Neste sentido, colabora, também, para uma relação mais ecologicamente sustentável da produção ao consumo, mas não apenas, pois há ainda a sustentabilidade social ao permitir interações entre os atores desse tipo de local de comercialização.

Os consumidores, ao buscarem pelos produtos das feiras, falam de uma peculiaridade de um consumidor que busca por qualidade alimentar, pela valorização cultural dos alimentos, inclusive de quem o produz, incorporando nas escolhas o aspecto do comer para além de um ato fisiológico, mecânico, mas também cultural e simbólico. Alguns depoimentos ressaltam essa percepção, como o da consumidora Janete, de Medianeira, já relatada ao longo desse trabalho, que diz se preocupar menos com o preço do produto e mais com a sua qualidade, pois tem medo de alguém de sua família sofrer uma intoxicação alimentar, além de evitar os alimentos ultraprocessados. Há também o depoimento da agricultora Rafaela, de 56 anos, de Medianeira:

O produto que eu trago aqui, trago de qualidade e não em quantidade, lá em casa as vezes deixo de fazer minhas coisinhas para trazer algo bom para aqui.

Angélica, também de Medianeira, 56 anos, compartilha de semelhante preocupação:

O nosso produto é de qualidade, a gente procura sempre oferecer 0 melhor, o frango é inspecionado acompanhado por veterinário, eu não tenho medo de vender. 
Rafael, 32 anos, de Medianeira, agricultor e feirante, demonstrou sua preocupação em manter uma postura coerente em relação à produção de qualidade e preocupação com a sustentabilidade, embora não tenha utilizado essa expressão:

\begin{abstract}
Eu acho isso (a produção responsável) o futuro, porque a cada dia que passa a gente pega aí alterações em alimentos, adulterações no leite, na carne, porque, porque a indústria quer produção rentabilidade entendeu, e o consumidor não, a cada dia que passa ele quer mais qualidade, ele quer essa proximidade, ele quer saber se sua vaca está doente, tem carrapato, se ela é saudável, o que ela come, e com isso eu acho muito importante pra quem produz certo, porque a indústria não pode fornecer isso ao consumidor e nós podemos. Eu acho a feira a principal janela, o que a gente precisa é conscientizar o povo que o produto da feira quem sabe não é o mais bonito, a fruta a verdura, mas ele é mais saudável, entendeu, então é isso que a gente tem que divulgar, mas eu acredito que essa proximidade é o futuro, todo mundo quer comer coisas boas, então a gente traz o melhor pra feira, para tentar agradar o nosso cliente (Rafael, 32 anos, Medianeira).
\end{abstract}

Seu Almir, 54 anos, morador de Marechal Cândido Rondon, se diz frequentador assíduo da feira; ele adquire, sobretudo, frango caipira, linguiça, queijo e hortaliças. Para ele, a qualidade é o diferencial: "Os produtos são mais saudáveis, cem por cento melhor do que no mercado, não pode nem comparar”.

Todos os consumidores entrevistados, os já fregueses e, também, os menos assíduos, afirmaram ter a compreensão de que os produtos que adquirem nas feiras são melhores e mais saborosos e que consideram a valorização a esse tipo de mercado uma forma de responsabilidade, como consumidores, em colaborar para a sua continuidade, embora tenham consciência das mudanças nas formas de aquisição de alimentos que se ampliam. No entanto, acreditam exercer um papel muito importante para a manutenção das feiras em seus municípios.

\title{
6 Considerações finais
}

As discussões trazidas nesta pesquisa tiveram por intuito chamar a atenção para a importância das feiras como redes curtas de comercialização, no que se refere à sua múltipla sustentabilidade na região Oeste do Paraná, especificando dois municípios da região. Considerando as relações existentes entre agricultoresfeirantes e consumidores no que se refere às diversas relações que se estabelecem entre estes atores, desde o processo de comercialização, a amizade construída e o ato de se tornar freguês.

A sustentabilidade econômica se dá em função de que a atividade na feira representa, para todos os agricultores e agricultoras feirantes entrevistados, importante - quando não a principal - fonte de renda familiar. Ela se comprova, ainda, por permitir formas de negociação informal dos preços praticados que podem ser aplicados em comum acordo entre quem vende e quem compra.

A sustentabilidade social e cultural está dada na sociabilidade que permeia as práticas comerciais entre os atores; nas relações de confiabilidade que se estabelecem entre as partes; nos tipos e qualidade dos alimentos ofertados pelos 
agricultores e buscados pelo consumidor e pela perpetuação da cultura de um comércio que permite relações mais afetivas e próximas em torno do alimento e das práticas alimentares.

Tais discussões são relevantes e contribuem para o avanço do debate sobre as feiras da agricultura familiar no contexto do desenvolvimento rural sustentável, sobretudo, situando-os ao Oeste do Paraná; além de colaborar para ampliar o status das feiras como lugares de grande importância no que se refere às trocas sociais, culturais e econômicas, estabelecendo uma centralidade quando se trata de redes curtas de comercialização e abastecimento alimentar nas áreas urbanas.

Observamos que em ambas as feiras, a cultura, a interação, a troca, a sustentabilidade, a comercialização e o consumo formam um sistema interacional em que ganham os agricultores-feirantes, os consumidores eventuais e os fregueses. Benefícios para aqueles que enxergam nas feiras uma referência de práticas alimentares saudáveis. Benefícios também para os agricultores e agricultoras familiares que investem em uma produção rural sustentável compreendendo ser possível o equilíbrio entre produção alimentar e respeito à natureza, ainda que estando inseridos em um contexto regional da centralização da monocultura da soja e do milho. Nesse sentido, os agricultores-feirantes vão reagindo em uma atividade de produção em pequena escala de alimentos, mas de grande importância para abastecer a mesa das famílias urbanas da região, na turbulência do cotidiano; competindo assim, com grandes indústrias que ampliam rapidamente o monopólio da produção e distribuição de alimentos.

Os consumidores e os fregueses por sua vez são personagens-chave nesse processo, por persistirem na utilização dessa forma de mercado para o abastecimento alimentar cotidiano, mesmo em face das praticidades oferecidas pelos supermercados. Demonstram assim, valorização por uma alimentação minimamente processada. Por meio dos relatos, também constatamos que os frequentadores das feiras são atraídos não apenas pela opção de alimentos mais saudáveis, frescos, de origem que consideram como sendo confiável, mas também porque o espaço da feira lhes proporciona importantes relações e interações com os agricultores, e com outros frequentadores.

Para os agricultores e agricultoras as feiras não são apenas importante fonte de renda, mas também uma manifestação - às vezes consciente e, às vezes, automática - enquanto representação de seus costumes e modos de vida e reprodução social e cultural. Atuam assim, como agentes de preservação da cultura alimentar e da segurança alimentar.

Outro ponto relevante desta pesquisa era comparar a dinâmica entre as duas feiras. Neste sentido, observamos que a de Medianeira se sobressai em função da condução da cooperativa atrelada às suas atividades. Com a COAFASO, os agricultores familiares tiveram a oportunidade de se inserirem em um outro nicho de mercado, que foi a participação dos programas governamentais na aquisição de alimentos.

Há diferentes estudos no que tange às questões voltadas à agricultura familiar que muito contribui e enriquece a discussão, sobretudo, no campo teórico. A realização da pesquisa empírica, no entanto, apresenta o quão complexo é estabelecer conceituação e tipificação linear para a agricultura familiar e ruralidade 
brasileira, pois é uma atividade muito dinâmica, diversa e múltipla em função dos diversos territórios dos quais fazem parte.

Um dos importantes desafios, em função disso, está em compreender mais profundamente o que estimula os agricultores familiares a se manter na atividade em tempos de tanta pressão do modelo capitalista contemporâneo que acarreta a desvalorização da agricultura familiar ao passo que estimula o avanço da monocultura de produção intensiva, do uso de agrotóxicos, que por consequência tem o intuito de causar um esvaziamento (de pessoas) do campo.

Por fim, esperamos que este trabalho contribua para aprofundamento das questões aqui tratadas, no que se refere às cadeias curtas, destacando a feira da agricultura familiar. Compreendemos que as feiras representam lugares de "contramovimentos", que é também de resistência, que muito podem contribuir para a segurança alimentar e para sustentabilidade da agricultura familiar brasileira.

\section{REFERÊNCIAS}

ABRAMOVAY, R. Agricultura familiar e serviço público: novos desafios para a extensão rural. In: Cadernos de Ciência \& Tecnologia, Brasília, v. 15, n. 1, p. 137-157, jan./abr. 1998. Disponível em:<https://seer.sct.embrapa.br/index.php/cct/article/view/8932/5051>. Acesso em: 19 nov. 2018.

. Paradigmas do capitalismo agrário em questão. São Paulo, Anpocs/Unicamp/Hucitec,1992.

ANGULO, J. L. G. Mercado local, produção familiar e desenvolvimento: estudo de caso da feira de Turmalina, Vale do Jequitinhonha, MG. O.R. \& A. Revista de Administração da UFLA, v.5, n. 2, jul./dez., 2003. p. 96-109.

ARAÚJO, A. M.; RIBEIRO, E. M. Feiras e desenvolvimento: impactos de feiras livres do comércio urbano no Jequitinhonha. Revista Brasileira de Planejamento e Desenvolvimento, Curitiba, v. 7, n. 2, p. 300-327, mai./ago. 2018. Disponível em: <https://periodicos.utfpr.edu.br/rbpd>. Acessado em: 16 nov. 2018.

BRANDENBURG, A. Do rural tradicional ao rural socioambiental. Ambiente \& Sociedade, Campinas, v. 13, n. 2, p. 417-428, jul./dez. 2010.

BRASIL. Ministério da Saúde. Secretaria de Atenção à Saúde. Departamento de Atenção Básica. Guia alimentar para a população brasileira. $2^{\mathrm{a}}$ ed., Brasília: Ministério da Saúde, 2014.

CAMARANO, A. A. \& ABRAMOVAY, R. Êxodo rural, envelhecimento e masculinização no Brasil: panorama dos últimos cinquenta anos. Revista Brasileira de Estudos de População, v. 15, fasc. 2, p. 45-66, 1998. 
CARNEIRO, M. J. Ruralidades: novas identidades em construção. Estudos Sociedade e Agricultura, n. 11, out. 1998, p. 53-75.

. Identidades sociais: ruralidades no Brasil contemporâneo. Apresentação. In: MOREIRA, R. J. et al. (Orgs). Identidades sociais: ruralidades no Brasil contemporâneo. Rio de Janeiro: DP\&A, 2005, pp. 7-14. CARVALHO, M. de L. G. de;

SOUZA, M. de. Categorização/Classificação. In: Cadernos Cespuc, Belo Horizonte: n. 23, 2013, p. 13-18. Disponível

em:<periodicos.pucminas.br/index.php/cadernoscespuc/article/download/8298/7179 >. Acesso em: 15 nov. 2018.

COLOGNI, M. Pesquisa de satisfação de clientes: um estudo realizado na Cooperativa da Agricultura Familiar e Solidária do Oeste do Paraná - Unidade de Medianeira. Trabalho de Conclusão de Curso (Graduação), Faculdade Educacional de Medianeira, Medianeira, 2016.

COLOGNESE, S. A.; GREGORY, V.; SCHALLENBERGER, E. Tupãssi do mito à história. Edunioeste: Cascavel, 1999.

COLOGNESE, S. A.; STOFFEL, J. A. Organização produtiva da agricultura familiar no Oeste do Paraná. In: VANDERLINDE, T.; GREGORY, V.; DEITOS, N. J. (Orgs.)

Migrações e a construção do oeste do Paraná: século XXI em perspectiva. Cascavel: Coluna do Saber, 2007, p. 69-84.

GASTAL, M. L. et al. A Construção Social da Feira da Agricultura Familiar de Unaí, MG: referência sobre a conquista de mercado. Planaltina, DF: Embrapa Cerrados, 2016.

GRANOVETTER, M. Ação econômica e estrutura social: o problema da imersão. ERA eletrônica, v. 6, n. 1, art. 9, p. 1-41, jan./jun. 2007. Disponível em:

<http://www.scielo.br/pdf/raeel/v6n1/a06v6n1.pdf>. Acessado em: 20 set. 2018.

HARVEY, D. O espaço como palavra-chave. Em Pauta, Rio de Janeiro, v. 13, n. 35, p. 126 - 152, 2015. Disponível em:<www.e-

publicacoes.uerj.br/index.php/revistaempauta/article/download/18625/13595>

Acesso em: 13 ago. 2018.

IBGE. INSTITUTO BRASILEIRO DE GEOGRAFIA E ESTATÍSTICA. Diretoria de Pesquisas, Coordenação de População e Indicadores Sociais. Estimativas da população residente. 2018. Disponível em:

<https://cidades.ibge.gov.br/brasil/pr/medianeira/panorama>. Acesso em 13 abr. 2018.

. INSTITUTO BRASILEIRO DE GEOGRAFIA E ESTATÍSTICA. Censo Agropecuário 2006. Rio de Janeiro: IBGE, 2006. Disponível em: 
$<$ https://biblioteca.ibge.gov.br/visualizacao/periodicos/51/agro_2006.pdf $>$. Acesso em: 08 nov. 2018.

. INSTITUTO BRASILEIRO DE GEOGRAFIA E ESTATÍSTICA. Censo

Agropecuário 1995/1996. Rio de Janeiro: IBGE, 1996. Disponível em:

$<$ https://sidra.ibge.gov.br/pesquisa/censo-agropecuario/censo-agropecuario-1995$1996>$ Acesso em: 08 nov. 2018.

LIMA, R. de S. Práticas Alimentares e Sociabilidades em Famílias Rurais da Zona da Mata Mineira: mudanças e permanências. Tese (Doutorado), Universidade Federal de Viçosa, MG, 2015.

LIMA, R. de S., NETO, J.A.F., and FARIAS, R.C.P. Dinâmicas alimentares na relação rural urbano: o caminho entre o tradicional e o moderno. In: PRADO, S.D., et al. (Orgs.). Estudos socioculturais em alimentação e saúde: saberes em rede. Rio de Janeiro: EDUERJ, Série Sabor Metrópole, vol. 5, 2016, p. 59-79.

MEDEIROS, J. C. de. 0 turista vai à feira: usos e possibilidades do turismo cultural na feira de Currais Novos/RN. Trabalho de Conclusão de Curso (Graduação). Curso de Turismo, Universidade Federal do Rio Grande do Norte, 2012.

MINAYO, M.C.de S. (Org). Pesquisa Social: teoria, método e criatividade. Petrópolis: Vozes, 2016.

NASCIMENTO, D. M. A mulher no campo e avanço da agricultura familiar. In: MDA. MINISTÉRIO DO DESENVOLVIMENTO AGRÁRIO. 2018. Disponível em:<http://www.mda.gov.br/sitemda/noticias/mulher-no-campo-e-o-avan\%C3\%A70da-agricultura-familiar>. Acesso em 23 nov. 2018.

PAULA, M. B. ; SCOPEL, A. ; LIMA, R.S. As feiras da agricultura familiar na percepção do feirante e do consumidor: um estudo de caso no município de Francisco Beltrão. In: VII Congresso Nacional de Pesquisa em Ciências Sociais Aplicadas - CONAPE, Anais, Francisco Beltrão. 2018. p. 1047-1051.

PEREIRA, V. G; BRITO, T. P.; PEREIRA, S. B. A feira-livre como importante mercado para a agricultura familiar em Conceição do Mato Dentro (MG). In: Revista Ciências Humanas, Taubaté, v. 10, ed. 20, p. 67-68, dez. 2017. Disponível em: $<$ https://www.rchunitau.com.br/index.php/rch/article/view/383/239>. Acessado em 27 set. 2018.

POLANYI, K. A grande transformação: as origens da nossa época. $2^{\mathrm{a}} \mathrm{ed}$. Rio de Janeiro: Campus, 2000.

RAHMEIER, D. Agricultura Familiar na Mesorregião Oeste do Paraná: cooperativismo como forma de integração para a sustentabilidade dos estabelecimentos familiares. Tese (Doutorado). Universidade Estadual do Oeste do Paraná, Toledo, 2016. 
ROBERTO, C. E. O. et al. Impactos da feira livre sobre a comercialização, geração de renda e diversificação da produção agrícola no município Alegre-ES. In: Cadernos de Agroecologia. Anais do VI CLAA, X CBA e V SEMDF, v, 13, nº 1, Jul. 2018. p.1-6.

SCHNEIDER, S. Mercados e Agricultura Familiar. In: MARQUES, F. Charão; CONTERATO, M. A.; SCHNEIDER, S. (Orgs.). Construção de mercados e agricultura familiar: desafios para o desenvolvimento rural. Porto Alegre: EDUFRGS, 2016, p., 93-140.

. A pluriatividade na agricultura familiar [online]. 2nd ed. Porto Alegre: Editora da UFRGS, 2003. Estudos Rurais Series, 252 p. Disponível em: <http://books.scielo.org/id/b7spy/pdf/schneider-9788538603894.pdf>. Acesso em: 12 set. 2018.

. Reflexões sobre diversidade e diversificação agricultura, formas familiares e desenvolvimento rural. RURIS: Revista do Centro de Estudos Rurais, Campinas, v. 4, n. 1, p.,85-131, mar. 2010.

\section{STOFFEL, J. A. A Viabilidade da Agricultura Familiar: formas de organização} produtiva no Oeste do Paraná. Dissertação (Mestrado), Universidade Estadual do Oeste do Paraná, Toledo, 2004.

VEIGA, J. E., et al. O Brasil rural precisa de uma estratégia de desenvolvimento. Convênio FIPE - IICA (MDA/CNDRS/ NEAD), Série: Texto para discussão, n¹. 2001. Disponível em:

<https://www.cairu.br/biblioteca/arquivos/Agronegocios/Brasil_rural_precisa_estrat egia_desenvolvimento_1.pdf, acessado em 06/02/1019.

WANDERLEY, M. N. B. A valorização da agricultura familiar e a reivindicação da ruralidade no Brasil. Desenvolvimento e Meio Ambiente, v. 2., p. 29·37, jul/dez. 2000. Disponível em: <https://revistas.ufpr.br/made/article/download/22105/14471>. Acesso em: 19 nov. 2018.

. Raízes históricas do campesinato brasileiro. In: ENCONTRO ANUAL DA ANPOCS, 20, 1996, Caxambu, MG. Anais... Caxambu, 1996. Disponível em: <http://www.reformaagrariaemdados.org.br/sites/default/files/Ra\%C3\%ADzes\%20His toricas\%20do\%20Campesinato\%20Brasileiro\%20$\% 20$ Maria\%20de\%20Nazareth\%20Baudel\%20Wanderley\%20-\%201996.pdf>. Acessado em 19 nov. 2018.

Romilda De Souza Lima. Doutora em Extensão Rural pela Universidade Federal de Viçosa. Professora Adjunta da Universidade Estadual do Oeste do Paraná, dos cursos de graduação em Nutrição e do Programa de Pós-Graduação Stricto Sensu em Desenvolvimento Rural Sustentável.romislima2@gmail.com 
Ana Paula Cavali Fontana. Mestre em Desenvolvimento Rural Sustentável pela Universidade Estadual do Oeste do Paraná. Professora contratada pela SEED-PR atuando nas disciplinas de ciências e biologia e professora contratada pela Prefeitura Municipal de Medianeira-PR. anapaulacavali@hotmail.com

Como citar: LIMA, Romilda De Souza; FONTANA, Ana Paula Cavali. As feiras da agricultura familiar como território de práticas alimentares e sociabilidades. Redes, Santa Cruz do Sul, v. 24, n. 3, p. 75-100, set. 2019. ISSN 1982-6745. Disponível em: https://doi.org/10.17058/redes.v24i3.14119. 